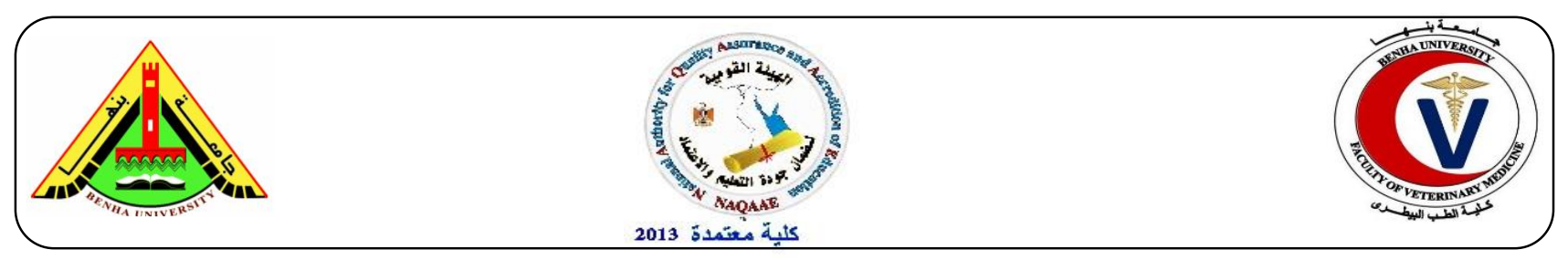

\title{
Potent Antibacterial Peptides from Enzymatically Hydrolyzed Hen Egg White Lysozyme
}

\author{
Dina, A. Awad ${ }^{1}$, Hamdi, A. Mohammed ${ }^{1}$, Adham, M. Abdou' ${ }^{1}$ Sobhy, A. El Sohaimy ${ }^{2}$ \\ ${ }^{1}$ Department of Food Hygiene, Faculty of Veterinary Medicine, Benha University, Egypt. \\ ${ }^{2}$ Food Technology ARID Land Research Institute, City of Scientific Research and Technology Application- \\ Borg Elarb-Alexanderia.
}

\section{A B S T R A C T}

Egg white is considered as a rich source of high quality proteins with various bioactive peptides. It considers the richest source of lysozyme which is a bacteriolytic enzyme. Our target was to produce potent peptides with cheap and simple method from lysozyme as a natural food preservative for further application in food. Lysozyme is mostly active against Gram positive bacteria than Gram negative bacteria. Various strategies have been used to increase antimicrobial activity of lysozyme against Gram-negative bacteria. Enzymatic hydrolysis of proteins can be used to release bioactive fractions using different enzymes to release bioactive fractions. Due to increasing demand for natural food preservatives, lysozyme has become increasingly important in food processing. Therefore, there is a need to develop an efficient and simple methodology for increasing its activity. So this research study the activity of lysozyme hydrolysates under different $\mathrm{pH}$ values using pepsin then determine the antibacterial using liquid broth method and determine the lytic activity. We found that lysozyme hydrolysates under $\mathrm{pH}$ 3.0 LzP3 gave the most antibacterial active peptide against Gram negative bacteria with more potency against Gram positive bacteria. On conclusion LzP3 contains bioactive peptides that can be applied for safety food biopreservation.

Keywords: Lysozyme, peptic hydrolysis, lytic activity, antibacterial activity.

(http://www.bvmj.bu.edu.eg)

(BVMJ-35(2): 150-156, 2018)

\section{INTRODUCTION}

The demands for natural antimicrobial compounds that are effective and non-toxic have greatly increased due to the rising of bacterial resistance against the synthetic antimicrobial agents. Moreover, limitation on the use of synthetic preservatives in food systems. So, exploring new food grade antimicrobial compounds from natural sources is a tall order. Recently, bioactive peptides with antibacterial activity have received a great attention in food industry, due to their low toxicity and unique biological mechanisms of disrupting the membrane of the pathogens (Davalos et al., 2004). One of the natural antimicrobial proteins, consider the most promising candidates for use in the biopreservation of food is hen egg white lysozyme (HEWL). The discovery of lysozyme attracted great interest in various industries due to its antibacterial activity and 
consider as generally regarded as safe GRAS. So, HEWL has been commercialized for application as a natural preservative in various food item (Masschalck and Michiels, 2003).

\section{Lysozyme (muramidase) is a single} polypeptide chain consisting of 129 amino acids, in which lysine is the $\mathrm{N}$-end amino acid and leucine is the C-end one. Its isoelectric point is10.7. It is a globular basic protein characterized by molecular weight of $14.3 \mathrm{kDa}$ and cross-linked by four disulfide bonds (Cegielska-radziejewska et al., 2008) which kills bacteria by cleaving the $\beta$-1,4-glycosidic bond between $\mathrm{C}-1$ of $\mathrm{N}$-acetyl muramic acid and $\mathrm{C}-4$ of $\mathrm{N}$-acetyl glucosamine residues of the peptidoglycan in the bacterial cell wall (Zhao et al., 2011). But, It is more potent against Gram positive bacteria than Gram negative bacteria.

Several strategies have been developed to extend the working spectrum of HWEL to be active against Gram-negative bacteria and/or increase its efficacy on Gram positive bacteria. From these strategies enzymatic hydrolysis which is a process conducted under mild conditions which can be easily controlled (Clemente, 2000). Most enzymatic modifications of dietary proteins are carried out by enzymes such as pepsin, trypsin, chymotrypsin or, papain under their respective optimal $\mathrm{pH}$ and temperature conditions. Bioactive peptide sequences are embedded within a parent protein where they are inactive and become active when released enzymatic hydrolysis. In the present study we applied many conditions for enzymatic hydrolysis of lysozyme and determine the best methods which produce the most potent antibacterial activity.

\section{Materials and methods}

\subsection{Materials:}

Native lysozyme chloride powder ( $\mathrm{pH}$ 3.6) from hen egg white. Its activity $22400 \mathrm{U} / \mathrm{mg}$ was purchased from Dalian Green snow Egg Products Development Co., LTD., China. Pepsin crystalline $(10000 \mathrm{U} / \mathrm{mg}$ obtained from porcine stomach mucus) obtained from Nacalai Tesque, INC. Kyoto, Japan. Micrococcus lysodeikticus were purchased from Sigma Chemical Co., St. Louis, and MO.USA.

\subsection{Bacterial strains:}

The bacterial strains E.coli (IFO 3301) and Bacillus Subtilis (NBRC 14462), were obtained from Animal Research Institute, Egypt. Both strains were maintained in trypticase soy broth with $10 \%$ glycerol at $20^{\circ} \mathrm{C}$. 2.3. Enzymatic hydrolysis of lysozyme:

Enzymatic hydrolysis occurred according to Carrillo et al. (2014) with some modification. About 80 milliliter of lysozyme solution $(0.1 \mathrm{~g} / 1 \mathrm{ml}$ in sterile distilled water) was mixed with $20 \mathrm{ml}$ of pepsin solution $(0.01 \mathrm{~g} / \mathrm{ml}$ buffer $\mathrm{pH} 2.0)$ to obtain an enzyme to-substrate ratio of 1:4 (wt/wt). This mixture was incubated with stirring at $37^{\circ} \mathrm{C}$ for $2 \mathrm{hr}$ after adjustment $\mathrm{pH}$ 3.0. The reaction was quashed by heating at $80^{\circ} \mathrm{C}$ for $10 \mathrm{~min}$. followed by direct cooling to produce lysozyme peptides (LzP3) kept at $4^{\circ} \mathrm{C}$ till use. Another enzymatic conditions was repeated under conditions $\mathrm{pH} 4.0$ instead of $\mathrm{pH}$ 3.0. to produce lysozyme peptides (LzP4).

\subsection{Measurement of Muramidase activity:}

The lytic or enzymatic activity of lysozyme and its digests (LzP3, LzP4) were measured against Micrococcus lysodeikticus cells according to a turbidimetric method, previously reported (Ibrahim et al., 1996) based on the decrease in turbidity of $1.9 \mathrm{ml}$ cell suspension $(170 \mu \mathrm{g}$ dry cells $\mathrm{ml}-1)$ in $50 \mathrm{mM}$ potassium phosphate buffer ( $\mathrm{pH}$ 6.0) following the addition of $100 \mu$ l portion of lysozyme or LzP3 or LzP4 solutions after equilibration to achieve constant absorbance. The decrease in absorbance at $450 \mathrm{~nm}$ was monitored using spectrophotometer. The enzymatic activity is expressed in as a percentage relative to native lysozyme. 


\subsection{Determination Protein concentration:}

Protein content of native lysozyme, LzP3 and LzP3 were determined by Bradford method using dye reagent at $595 \mathrm{~nm}$. Using Bovine serum albumin BSA $(0.2-1.4 \mathrm{mg} / \mathrm{mL})$ as a standard curve to calculate the protein content (Bradford, 1976).

\subsection{Antimicrobial Activity assay:}

Lysozyme, LzP produced at different $\mathrm{pH}$ readings were prepared to give a final concentration of $400 \mu \mathrm{g} / \mathrm{ml}$. As previously described (Ibrahim, et al., 2001), aliquots (400 $\mu 1)$ of trypticase soy broth were mixed with $200 \mu 1$ of the bacterial suspension (adjusted to a final concentration of $3 \log \mathrm{cfu} / \mathrm{ml}$ ), using a representative microorganism for Gram negative bacteria as E.coli and for Gram positive bacteria as bacillus subtilus then 200 $\mu \mathrm{l}$ of the samples were prepared to give a final concentration 200, 100, 50, $25 \mu \mathrm{g} / \mathrm{ml}$. A positive control was prepared without the addition of protein and negative control without addition of pathogen. The suspensions were incubated for $2 \mathrm{hr}$ at $37^{\circ} \mathrm{c}$, serially diluted in buffer $\mathrm{pH} 7.0$ and plated on trypticase soy agar. Colony-forming units were obtained after incubation of the plates at the specified temperature for $48 \mathrm{~h}$. All assays were performed in triplicates and the results are the means of three independent experiments.

\subsection{Statistical analysis:}

Statistical comparisons were made by using one-way analysis of variance (ANOVA). The results were considered significantly different with $\mathrm{P}<0.05$ as described by Clarke and Kempson (1997).

\section{RESULTS}

3.1. Antibacterial activity of native lysozyme and its peptic digests at different $\mathrm{pH}$ conditions:

We have examined the antibacterial activity of native lysozyme comparing with its peptic hydrolysates against a Gram-positive (Bacillus subtilus) and a Gram-negative bacterial strains (E.coli) as a function of increasing protein concentration when incubated with test bacteria at $37^{\circ} \mathrm{c}$ for $2 \mathrm{hr}$. The lysozyme had low antibacterial activity against E.coli while peptic hydrolysate pH 3.0 (LzP3) had more potent antibacterial activity even though peptic hydrolysate $\mathrm{pH} 4.0$ (LzP4) in comparing with positive control. The effect of antibacterial activity of native lysozyme, LzP3 and $\mathrm{LzP} 4$ on E.coli were a dose-dependent. As at concentration $25 \mu \mathrm{g} / \mathrm{ml}$ we found lysozyme had the lowest bacterial inhibition with a mean value $4.81 \pm 0.28$, but the peptic lysozyme hydrolysate $(\mathrm{LzP} 3)$ gave the highest bacterial inhibition with a mean value $1.81 \pm 0.08$ against E.coli (table1). With increasing the protein concentration we found that peptic lysozyme hydrolysate (LzP3) prevented the bacterial growth at concentration $200 \mu \mathrm{g} / \mathrm{ml}$. While lysozyme still not active against E.coli with a mean value $3.31 \pm 0.08$. As in Table2 illustrated the antibacterial activity of lysozyme comparing with its peptic hydrolysates against a Gram-positive (Bacillus subtilus). The lysozyme had more potent antibacterial activity at higher concentrations $100 \mu \mathrm{g} / \mathrm{ml}$ while it also effected on Bacillus subtilus at 25, $50 \mu \mathrm{g} / \mathrm{ml}$ with a mean value $4.81 \pm 0.28$ and $4.11 \pm 0.18$ respectively. So the effect was in a dose dependent manner. On the other hand, we found that lysozyme hydrolysates at different pH LzP3 and LzP4 inhibit the growth of the Bacillus subtilus at all concentrations.

\subsection{Lytic activity of peptic hydrolysates} comparing with native lysozyme:

Figure 1 showed the changes in lytic activity of the produced hydrolysates comparing with native lysozyme. Where LzP3 had the lowest lytic activity $20 \%$ then followed by LzP4 79\% comparing with native lysozyme which act $100 \%$ lytic activity. 
Table 1: Comparison the Antibacterial activity between lysozyme, LzP3 and LzP4. against Escherichia coli. The assays were performed using liquid broth method where test bacteria incubated with protein samples in different concentrations for $2 \mathrm{~h}$ then plated for $18 \mathrm{~h}$ in presence of control where bacterial culture with a mid-logarithmic phase incubated with sterile milli $\mathrm{Q}$ water instead of test protein. The assay repeated 3 times.

\begin{tabular}{|c|c|c|c|c|}
\hline Strain & \multicolumn{4}{|c|}{$\begin{array}{l}\text { Antibacterial activity after } 2 \mathrm{hr} \text { against } E \text {.coli }\left(10^{3}\right) \\
\text { (Mean } \log \pm \mathrm{SE} \text { ) }\end{array}$} \\
\hline 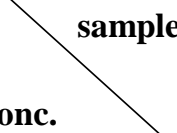 & $\begin{array}{c}\text { Native } \\
\mathrm{lz}\end{array}$ & LzP3 & LzP4 & $\begin{array}{c}\text { Negative } \\
\text { control }\end{array}$ \\
\hline $0 \mu \mathrm{g} / \mathrm{ml}$ & - & - & - & $5.93 \pm 0.47^{\mathrm{a}}$ \\
\hline $25 \mu \mathrm{g} / \mathrm{ml}$ & $4.81 \pm 0.28^{\mathrm{a}}$ & $1.81 \pm 0.08^{\mathrm{c}}$ & $3.81 \pm 0.18^{c}$ & \\
\hline $50 \mu \mathrm{g} / \mathrm{ml}$ & $4.11 \pm 0.18^{\mathrm{a}}$ & $1.41 \pm 0.11^{\mathrm{c}}$ & $3.11 \pm 0.08^{c}$ & \\
\hline $100 \mu \mathrm{g} / \mathrm{ml}$ & $3.81 \pm 0.40^{\mathrm{a}}$ & $1.01 \pm 0.23^{\mathrm{c}}$ & $2.01 \pm 0.41^{b}$ & \\
\hline $200 \mu \mathrm{g} / \mathrm{ml}$ & $3.31 \pm 0.08^{\mathrm{a}}$ & ND & $1.92 \pm 0.08^{c}$ & \\
\hline
\end{tabular}

Means within the same row having different superscripts are significantly different $(p \leq 0.05)$.

Table 2: Comparison the Antibacterial activity between lysozyme, LzP3 and LzP4. against Bacillus subtilus. The assays were performed using Liquid broth method for $2 \mathrm{~h}$ then determine CFU count. The assay was repeated 3 times. The assays were performed using liquid broth method where test bacteria incubated with protein samples in different concentrations for $2 \mathrm{~h}$ then plated for $18 \mathrm{~h}$ in presence of control where bacterial culture with a mid-logarithmic phase incubated with sterile milli $\mathrm{Q}$ water instead of test protein. The assay repeated 3 times.

\begin{tabular}{ccccc}
\hline Strain & \multicolumn{4}{c}{$\begin{array}{c}\text { Antibacterial activity after 2hr against Bacillus subtilus } \\
\left(10^{3}\right) \\
(\text { Mean } \log \pm \mathrm{SE})\end{array}$} \\
\hline sample & $\begin{array}{c}\text { Native } \\
\text { lz }\end{array}$ & LzP3 & LzP4 & $\begin{array}{c}\text { Negative } \\
\text { control }\end{array}$ \\
\hline $\mathbf{0} \boldsymbol{\mu \mathbf { g } / \mathbf { m l }}$ & - & - & - & $4.93 \pm 0.37^{\mathrm{a}}$ \\
\hline $\mathbf{2 5} \boldsymbol{\mu} \mathbf{g} / \mathbf{m l}$ & $1.81 \pm 0.08^{\mathrm{a}}$ & $\mathrm{ND}$ & $\mathrm{ND}$ & \\
\hline $\mathbf{5 0} \boldsymbol{\mu \mathbf { g } / \mathbf { m l }}$ & $1.01 \pm 0.28^{\mathrm{a}}$ & $\mathrm{ND}$ & $\mathrm{ND}$ & \\
\hline $\mathbf{1 0 0} \boldsymbol{\mu g} / \mathbf{m l}$ & $\mathrm{ND}$ & $\mathrm{ND}$ & $\mathrm{ND}$ & \\
\hline $\mathbf{2 0 0} \boldsymbol{\mu g} / \mathbf{m l}$ & $\mathrm{ND}$ & $\mathrm{ND}$ & $\mathrm{ND}$ \\
\hline
\end{tabular}

Means within the same row having different superscripts are significantly different $(p \leq 0.05)$. 


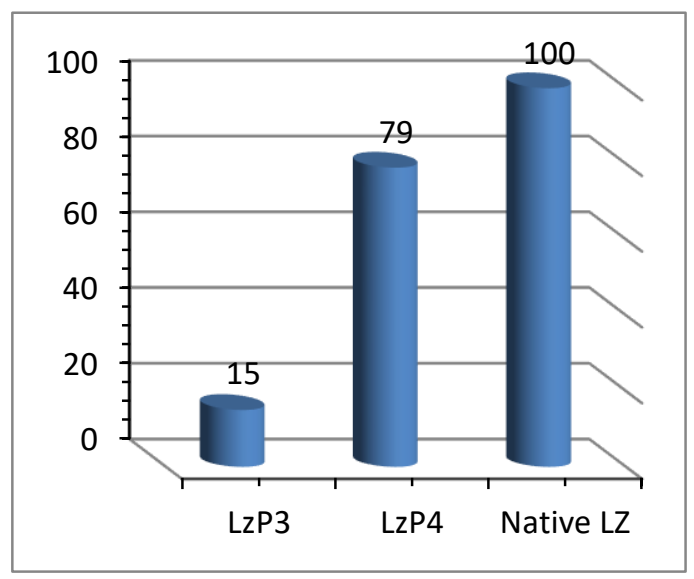

Fig.1. Comparison the lytic activity between lysozyme, LzP3 and LzP4. The assays were performed using turbidometric method. Aliquots $(100 \mu \mathrm{l})$ containing test protein in $50 \mathrm{mM}$ potaasium phosphate buffer, pH 6.5 were added to $1.9 \mathrm{ml}$ of $\mathrm{M}$. lysodeikticus cell suspensions as a substrate in the same buffer and was monitored at the absorbance $(450 \mathrm{~nm})$. The activity is expressed as the rate of decrease in absorbance per min of the initial velocity of reaction.

\section{DISCUSSION}

Various strategies have been used to increase antimicrobial activity of lysozyme against Gram-negative bacteria. Like a number of chemical modifications aimed at inserting a hydrophobic moiety (Ibrahim et al., 1993), or lypophilizing of lysozyme by a fatty acid having a different chain length (Liu et al., 2000). The current study was focused on the changes in the antibacterial activity of native lysozyme, after peptic hydrolysis at different $\mathrm{pH}$ LzP3 and LzP4. Peptic hydrolysis of native $\mathrm{LZ}$ to produce LzP3 acquired the most potent antibacterial activity. This due to some peptide is usually inactive when exists as a part of the parent protein but when released during food processing and hydrolysis become more potent (Davalos, et al., 2004). It was observed that the conditions of producing LzP3 were similar to gastric digestions which explain why peptic hydrolysis of lysozyme at $\mathrm{pH} 4.0$ less active than LzP3. On general lysozyme not active against Gram negative bacteria but LzP3 more potent against Gram negative bacteria where lysozyme is effective against Gram-positive bacteria only but it is largely ineffective against Gram-negative bacteria (Ibrahim et al., 2002).

Interestingly, According to fig.1 LzP3 had lowest lytic activity in the same time considered the most potent antibacterial activity that confirm that the peptides produced the most biologically active pepties can inhibit the bacterial growth without lytic activity and this inhibition was due to the most potent peptides produced. Our result agreed with (Ibrahim et al., 2001) who found antimicrobial peptides (internal peptide residues 98-112) within lysozyme that are effective against gram-negative bacteria, without lytic activity.

Lysozyme acts by lysing the cell wall of certain gram-positive bacteria by splitting b (1-4) linkages between $\mathrm{N}$-acetylmuramic acid and $\mathrm{N}$-acetylglucosamine of the peptidoglycan of bacterial cell walls. By contrast, it has limited bactericidal effect against gram-negative bacteria. As the peptidoglycan layer, being the substrate of lysozyme, is covered additionally by the outer membrane consisting of lipoproteins, lipopolysaccharides (LPS) and some hydrophobic peptides. The outer membrane serves as a barrier to the access of 
enzyme to its site of action. It is most probable that lysozyme can be entrapped in the outer membrane by LPS of Gram-negative bacteria and inactivated (Ibrahim et al. 1993 and Nakamura et al., 1997).

\section{Conclusion}

The gastric conditions produce the most biologically active antibacterial peptides which show potent activity against Gram negative bacteria and also become more potent against Gram positive bacteria without lytic activity. Although lysozyme although had the highest lytic activity, it showed no activity against Gram negative bacteria. So lysozyme hydrolysates at $\mathrm{pH} 3.0$ can be used as food grade antibacterial agent from natural sources against bacterial growth.

\section{REFERENCES}

Bradford, M.M. (1976): A rapid and sensitive method for the quantification of microgram quantities of protein utilizing the principle of protein-dye binding. Anal Biochem 72(2):248-254.

Carrillo, W.; García-Ruiz, A.; Recio, I. and Moreno-Arribas, M. V. (2014): Antibacterial activity of hen egg white lysozyme modified by heat and enzymatic treatments against oenological lactic acid bacteria and acetic acid bacteria. Journal of Food Protection, 77(10), 1732-9.

Cegielska-radziejewska, R.; Leśnierowski, G. and Kijowski, J. (2008): Properties and Application of Egg White Lysozyme and Its Modified Preparations - a Review. Polish Journal of Food and Nutrition Sciences, 58(1), 5-10.

Clarke, G.M. and Kempson, R.E. (1997): Introduction to the design and analysis of experiments. Arnold, a member of the Holder Headline Group. 1st ed., London, UK.

Clemente, A. (2000): Enzymatic protein hydrolysates in human nutrition. Trends in Food Science and Technology, 11(7), 254-262.

Davalos, A.; Miguel, M.; Bartolomé, B. and López-Fandiño, R. (2004): Antioxidant activity of peptides derived from egg white proteins by enzymatic hydrolysis. Journal of Food Protection, 67, 19391944.

Ibrahim, H.R.; Higashiguchi, S.; Juneja, L. R.; Kim, M. and Yamamoto, T. (1996): A Structural Phase of Heat-Denatured Lysozyme with Novel Antimicrobial Action. Journal of Agricultural and Food Chemistry, 44(6), 1416-1423.

Ibrahim, H. R.; Kobayasi, K. and Kato, A. (1993): Length of hydrocarbon chain and antimicrobial action to Gramnegative bacteria of fatty acylated lysozyme. J Agr Food Chem, 41(7), 1164-1168.

Ibrahim, H.R.; Thomas, U. and Pellegrini, A. (2001): A Helix-Loop-Helix Peptide at the Upper Lip of the Active Site Cleft of Lysozyme Confers Potent Antimicrobial Activity with Membrane Permeabilization Action. The Journal OF Biological Chemistry Vol. 276, No. 47, Issue of November 23, pp. $43767-$ 43774.

Liu, S.T.; Sugimoto T.; Azakami H. and Kato A. (2000): Lipophilization of lysozyme by short and middle chain fatty acids. J. Agric. Food Chem., 48, 265-269.

Masschalck B, Michiels, C.W. (2003): Antimicrobial properties of lysozyme in relation to food borne vegetative 
bacteria. Crit Rev Microbiol 29:191214.

Nakamura, N.K.; Furukawa N.; Matsuoka, M.; Takahashi T. and Yamanaka Y. (1997): Enzyme activity of lysozyme-dextran complex prepared by high-pressure treatment. Food Sci. Tech. Int. 3, 235238.

Zhao, L.; Sun, J. S. and Sun, L. (2011): The gtype lysozyme of Scophthalmus maximus has a broad substrate spectrum and is involved in the immune response against bacterial infection. Fish and Shellfish Immunology, 30(2), 630-7. 